\title{
Admit One's Driving Offences or Attribute Them to Others: An Exploratory Study Among a Sample of Cameroonian Drivers
}

\author{
Sandrine Gaymard \\ University of Angers, \\ Laboratoire de Psychologie des Pays de la Loire (LPPL, EA 4638), \\ Maison de la Recherche Germaine Tillion, France \\ Corresponding Author \\ Jean-Claude Etoundi \\ University of Angers, \\ Laboratoire de Psychologie des Pays de la Loire (LPPL, EA 4638), \\ Maison de la Recherche Germaine Tillion, France
}

Doi: $10.2478 / \mathrm{mjss}-2018-0125$

\begin{abstract}
In the field of social thinking the question of norms give rise to several publications. Moreover there exists no study in this theoretical framework concerning Cameroon drivers' relationship with the rule. In order to understand this, a group of 50 motorists filled out a characterization questionnaire on driving, purposely oriented to the use of the mobile. The instructions to the drivers were to fill it out for themselves (standard condition) and for other drivers (substitution condition). The results confirm the role of the substitution instructions in bringing to light inadmissible offences with standard instructions. It can be concluded that the Cameroon drivers are well aware of the rule and that they tend to attribute the greatest transgressions to other drivers.
\end{abstract}

Keywords: Cameroon drivers; social psychology; transgressions; social influence

\section{Introduction}

\subsection{The concept of Social representations}

The concept of social representations introduced by Moscovici in 1961 gave rise to many works and has become a leading concept in social psychology (e.g. Abric, 1993; Bauer \& Gaskell, 1999; Farr, 1987, 1993; Howarth, 2006; Moscovici, 1998, 2001; Mugny \& Carugati, 1989; Wagner, 1993). This concept, which translates the appropriation of reality by common sense, points to a dynamic process of collective construction. Moscovici defines a social representation as "...a system of values, notions and practices with a dual vocation. First of all, to instate an order that gives individuals the possibility of finding their bearings in the social and material environment and to dominate it. Then to ensure the communication between the members of a community " (Moscovici, 1984 , p.10-11, our translation). In the field of social thinking, the question of norms is not independent of the problems of social influence as research shows. Moscovici's works on minority influence (1976) have questioned the supremacy of the unilateral and majority influence based on conformity (Asch, 1951). In effect, through conversion, the minority is capable of convincing a majority that the former is right and it has been shown that the most important aspect of behavioral style is consistency (Faucheux \& Moscovici, 1967). For Moscovici (1991), the great turning is the passage from deviancy to active minority. The deviant is thus qualified in relation to the majority group it goes against; this starts from a framework that is set down by the majority. On the other 
hand the active minority defines its own framework; it is inscribed in innovation, with the creation of new norms. Sammut \& Bauer (2011) defined the following eight modalities of social influence: Leadership of masses; Imitation and contagion; Normalising and framing for future reference; Conformity; Obedience to authority; Persuasion: convincing by elaboration or simple cues; Conversion and Resistance to change, before proposing an integrative model: "the cycle of common sense". This cycle is based on 3 processes: normalization, assimilation of new arrivals and deviants, then accommodation: "The majority accommodates the minority by making concessions and by resetting the consensus on a new position." (Sammut \& Bauer, 2011, p.105). The theory of conditionality (Gaymard, 2014; Gaymard \& Tiplica, 2014) gives a choice position to norms in the field of social thinking by defending their negotiable character and showing the influence of reference models (Gaymard, 2009). Starting from the conditionality of individual practices, this approach highlights legitimate transgressions in the representation and questions the border established by the central core Theory of social representations (Abric, 1993). According to this theory there are central, absolute, shared elements in the core and peripheral, individual, negotiable elements in the periphery. For the theory of conditionality norms include normative latitudes; divergence from the norm is therefore integrated in the system (Gaymard, 2014).

This field has the particularity of articulating the study of normative aspects with specific methodologies. The substitution method, which consists in asking the person to reply in place of another was initially proposed by Flament (1999). Via the instruction which is diversely formulated, and the analysis strategy, this method can make it possible to illustrate the influence of certain reference groups on the social representation (Flament, 1999; Gaymard, 2003; 2009). These studies show that under a standard condition, the groups are influenced by other reference models, which can be teaching staff, parents or peers for example (Flament, 1999; Gaymard \& Bessin, 2017). This method can also allow normative pressure to be removed knowing that certain objects of social representations are more sensitive and this sensitivity manifests itself in the answers, by social desirability. Generally this technique shows the capacity of individuals to put themselves in the place of others, to produce other representations than their own and it confirms the influence of reference groups on individual answers (Campbell, Muncer, Guy \& Banim, 1996 ; Flament, 1999 ; Gaymard, 2014).

\subsection{Road safety in Cameroon.}

As everywhere else on the world, road accidents are a major public health concern in Cameroon; these are very often fatal, or cause more or less severe disabilities. This question is all the more preoccupying in developing countries like Cameroon since they form $85 \%$ of global deaths due to road accidents (Sobngwi-Tambekou et al., 2010).

From studies and surveys dealing with the problem of road accidents in Cameroon it can be seen that the main causes of these are as everywhere else above all of human origin. Human causes are responsible for $90 \%$ of accidents, and are linked to speeding, not using safety belts, driving without qualification (lack of driving licence or not corresponding to the vehicle's category) or drunk driving (Tikouoka, 2001; WHO, 2013).

To these human causes can be added the technical condition of vehicles and the poor condition of road infrastructures. Concerning the technical condition of the vehicles it can be noted that the great majority of vehicles on the road are second, third or even fourth hand. One can add the fact that they present major faults due to their owners' negligence. Among these faults, can be mentioned: faulty braking system, lack of safety belt and worn tires. The recent enforcement of frequent and regular inspections has not been satisfactory so far because of the corruption that goes along with these procedures (Bounoungou, 2015; Dipita, 2012; Ngapout, 2015).The poor condition of highway infrastructures is also an important element to be taken into account in the analysis of road accidents in Cameroon. The section Yaoundé-Douala, Douala-Bafoussam, Bafoussam-Yaoundé has notably been renamed "the death triangle" since $70 \%$ of the road accidents occur here. Concerning the section Yaoundé-Douala particularly, $243 \mathrm{~km}$ long, McGreevy et al. (2014), referring to a police investigation into the statistics between 2004 et 2007, relate that the number of casualties over a distance of $100000 \mathrm{~km}$ is 35 times as great on this section compared with figures over the same 
distance in Europe or the United States. This abnormally high percentage of accidents on this section can be explained mainly by the narrowness and the highly damaged state of the road, the dangerous bends linked to poor visibility and the lack of public lighting.

With more widespread access to the mobile phone in the last few years, the use of the mobile while driving is added to these longstanding, recurring causes. If it is true that there exist no official statistics showing the proportion of accidents resulting from the use of the mobile in Cameroon; nevertheless there can be found testimonies of law-enforcement officers and news items in the papers (Cameroun tribune, 2010). Given the magnitude of this phenomenon in the last few years and with a view to discouraging drivers from using this means of communication, Cameroon legislators have provided for a fine of CFA F 25000 but also suspension of the driving licence for a maximum period of one year in compliance with article eleven of the Highway Code of the Central African Economic and Monetary Community (CAEMC), adopted on 3 August 2001. This particularly heavy fine for the ordinary Cameroonian has not yet persuaded drivers not to use the mobile when driving since it is common to observe people phoning while driving everywhere. It must also be mentioned that unlike other countries such as France, legislators have not pronounced on the use of a kit or bluetooth while driving. It is just said that the use of the mobile while driving is forbidden. However we are forced to recognize that on certain car rental sites the following can be found "Remember that the use of mobile phones is forbidden while driving in Cameroon. You can use mobile free hand kit... ". It is therefore impossible to know the figures for the use of a kit or bluetooth but Cameroonians are well aware of this equipment which is a part of technological development (Lokoua, 2012).

The lack of apprenticeship for driving correctly, police officers' laxness and transporters who do not always apply regulations in force certainly contribute greatly to the acceptance of this practice. Be that as it may, this state of things is problematical and leads us to ask fundamental questions about the representation that Cameroon drivers have of these transgressions. Thus although certain works show the importance of road conditionality (Gaymard, 2007, 2009; Gaymard et al., 2011), it is specified that these legitimate transgressions can not be based on prohibitions such as the fact of drunk driving or phoning when driving. In other words drivers justify failure to respect rules such as the speed limit by circumstances like being in a hurry, but they can not justify these transgressions by relying on formal bans or criminal situations. In the case of Cameroon drivers, the question can be asked whether they are fully aware of these bans. The hypothesis is put forward that standard condition will be significantly different to the substitution condition.

\section{Method}

\subsection{Tool and analysis}

We devised a characterization questionnaire (Table 1) which is a typical tool in the study of social representations (Flament \& Rouquette, 2003; Gaymard \& Maurin, 2017; Gaymard, Tiplica, Kho \& Wong, 2015). This questionnaire is composed of 9 items voluntarily linked mostly to the use of the mobile. As in certain countries the use of the mobile while driving is allowed with the appropriated equipment, situations using the mobile while driving were presented in relation to equipment (kit or bluetooth). It contains 5 more respectful conditions (use of the mobile with equipment; respecting the speed limits; courtesy; concentration at the wheel and mobile off) and 4 transgression conditions (calling without equipment; answering without equipment; texting while driving; being aggressive while driving). The questionnaire was filled out in standard condition (the drivers answer for themselves) and in substitution condition (they answer as Cameroonians in general would do).

The use of the characterization questionnaire requires the following stages to be respected: the drivers must first of all choose the 3 most characteristic items of their driving and then the 3 least characteristic items of their driving (standard condition). The same procedure is adopted in a second stage where the drivers must choose as Cameroonian drivers would do in general (substitution condition). A specific notation between the least and the most characteristic is attributed. According to the Shapiro-Wilk normality test, the distribution of scores cannot be considered as being normal for a significance level of $1 \%$. Thus, we used the Wilcoxon signed ranks test. 
Table 1: Characterization questionnaire: list of items

\begin{tabular}{l}
\hline \hline Use of mobile with kit or bluetooth \\
\hline Respect of speed limits \\
\hline Calling without kit or bluetooth \\
\hline Courtesy while driving \\
\hline Answering without kit or bluetooth \\
\hline Texting while driving \\
\hline Concentration while driving \\
\hline Turning off mobile while driving \\
\hline Being aggressive while driving \\
\hline
\end{tabular}

\subsection{Population of the study}

Following the questionnaire certain data were collected from the participants. The population is composed of 50 male drivers average age $38.04(S D=7.53)$ holding a driving licence for 13.9 years $(S D=9.46)$ on average. The average number of accidents declared is $2.26(S D=1.87)$. Among the drivers, $60 \%$ are seen to use the mobile quite freely without any equipment, $30 \%$ the free hand kit from time to time and $10 \%$ the bluetooth. The sample questioned have varied occupations. The categories most represented being taxi drivers, public transport drivers and truck drivers (42\%), followed by private driver and civil servant $(20 \%)$, then by companies executive and employees $(14 \%)$, and finally by tradesperson and teachers $(10 \%)$.

These drivers who mainly use the Yaoundé-Obala section were interviewed on their parking zones (bus station and truck depot) for some and by appointment at their place of work or at home for firm employees and private individuals.

\section{Results}

Concerning respectful conditions, tables 2 and 3 indicate that respect of speed limits is declared more characteristic in standard $(\mathrm{Mdn}=3)$ than in substitution condition $(\mathrm{Mdn}=1), Z=5.50, p<$ .001 , with a large effect size $(r=.55)$ (Cohen, 1988; Pallant, 2007). Courstesy while driving is declared more characteristic in standard $(\mathrm{Mdn}=2)$ than in substitution condition $(\mathrm{Mdn}=1), Z=$ $3.68, p<.001$, with a medium effect size $(r=.37)$, and concentration while driving is declared more characteristic in standard $(M d n=3)$ than in substitution condition $(M d n=2) Z=5.48, p<.001$, with a large effect size $(r=.55)$.

Table 2: Comparison between standard (ST) and substitution (SUB) instructions of the respectful conditions (see table 1).

Ranks

\begin{tabular}{|c|c|c|c|c|}
\hline & & $\mathrm{N}$ & Mean Rank & Sum of Ranks \\
\hline \multirow[t]{4}{*}{ SUB - ST Use of mobile with kit ... } & Negative Ranks & $20^{(a)}$ & 17.20 & 344.00 \\
\hline & Positive Ranks & $11^{\text {(b) }}$ & 13.82 & 152.00 \\
\hline & Ties & $19^{(\mathrm{c})}$ & & \\
\hline & Total & 50 & & \\
\hline \multirow[t]{4}{*}{ SUB - ST Respect of speed limits } & Negative Ranks & $37^{(\mathrm{a})}$ & 19.00 & 703.00 \\
\hline & Positive Ranks & $0^{(\mathrm{b})}$ & .00 & .00 \\
\hline & Ties & $13^{(\mathrm{c})}$ & & \\
\hline & Total & 50 & & \\
\hline \multirow[t]{4}{*}{ SUB - ST Courtesy } & Negative Ranks & $30^{(a)}$ & 20.53 & 616.00 \\
\hline & Positive Ranks & $8^{(\mathrm{b})}$ & 15.63 & 125.00 \\
\hline & Ties & $12^{(\mathrm{c})}$ & & \\
\hline & Total & 50 & & \\
\hline \multirow[t]{4}{*}{ SUB - ST Concentration } & Negative Ranks & $37^{(\mathrm{a})}$ & 19.00 & 703.00 \\
\hline & Positive Ranks & $0^{(\mathrm{b})}$ & .00 & .00 \\
\hline & Ties & $13^{(\mathrm{c})}$ & & \\
\hline & Total & 50 & & \\
\hline
\end{tabular}




\begin{tabular}{llccc}
\hline & & $\mathrm{N}$ & Mean Rank & Sum of Ranks \\
\hline SUB - ST Turning off mobile & Negative Ranks & $16^{(\text {a) }}$ & 15.00 & 240.00 \\
& Positive Ranks & $12^{(\text {b) }}$ & 13.83 & 166.00 \\
& Ties & $22^{(\text {c) }}$ & & \\
& Total & 50 & & \\
& & & & \\
\hline (a) SUB $<$ ST & & & & \\
(b) SUB $>$ ST & & & \\
(c) SUB $=$ ST & &
\end{tabular}

Table 3: Test Statistics ${ }^{(b)}$

\begin{tabular}{cccccc}
\hline & $\begin{array}{c}\text { SUB - ST Use of } \\
\text { mobile with kit } \ldots\end{array}$ & $\begin{array}{c}\text { SUB - ST Respect } \\
\text { of speed limits }\end{array}$ & $\begin{array}{c}\text { SUB - ST } \\
\text { Courtesy }\end{array}$ & $\begin{array}{c}\text { SUB - ST } \\
\text { Concentration }\end{array}$ & $\begin{array}{c}\text { SUB - ST } \\
\text { Turning off } \\
\text { mobile }\end{array}$ \\
\hline Z & $-1.963^{(\text {a) }}$ & $-5.500^{(a)}$ & $-3.681^{(a)}$ & $-5.479^{(a)}$ & $-.897^{(a)}$ \\
\hline $\begin{array}{c}\text { Asymp. Sig. } \\
(2 \text {-tailed })\end{array}$ & .050 & .000 & .000 & .000 & .370 \\
\hline
\end{tabular}

(a) Based on positive ranks.

(b) Wilcoxon Signed Ranks Test

Concerning transgression conditions, Tables 4 and 5 indicate that calling without kit or bluetooth is declared more characteristic in susbtitution $(M d n=3)$ than in standard condition $(M d n=2), Z=5.21$, $p<.001$, with a large effect size $(r=.52) ; \quad$ answering without kit or bluetooth is declared more characteristic in susbtitution ( $M d n=3$ ) than in standard condition $(M d n=2), Z=4.27, p<.001$, with a medium effect size $(r=.43)$, texting while driving is declared more characteristic in susbtitution $(M d n=2)$ than in standard condition $(M d n=1) Z=3.50, p<.001$, with a medium effect size $(r=.35)$; being aggressive while driving declared more characteristic in susbtitution $(M d n=3)$ than in standard condition $(M d n=1) Z=5.64, p<.001$, with a large effect size $(r=.56)$.

Table 4: Comparison between standard (ST) and substitution (SUB) instructions of the transgression conditions (see table 1).

Ranks

\begin{tabular}{|c|c|c|c|c|}
\hline & & $\mathrm{N}$ & Mean Rank & Sum of Ranks \\
\hline \multirow[t]{4}{*}{ SUB - ST Calling without kit... } & Negative Ranks & $2^{(a)}$ & 12.00 & 24.00 \\
\hline & Positive Ranks & $36^{(b)}$ & 19.92 & 717.00 \\
\hline & Ties & $12^{(\mathrm{c})}$ & & \\
\hline & Total & 50 & & \\
\hline \multirow[t]{4}{*}{ SUB - ST Answering without kit... } & Negative Ranks & $5^{(a)}$ & 11.50 & 57.50 \\
\hline & Positive Ranks & $29^{(b)}$ & 18.53 & 537.50 \\
\hline & Ties & $16^{(\mathrm{c})}$ & & \\
\hline & Total & 50 & & \\
\hline \multirow[t]{4}{*}{ SUB - ST Texting while driving } & Negative Ranks & $6^{(a)}$ & 14.00 & 84.00 \\
\hline & Positive Ranks & $25^{(b)}$ & 16.48 & 412.00 \\
\hline & Ties & $19^{(\mathrm{c})}$ & & \\
\hline & Total & 50 & & \\
\hline \multirow[t]{4}{*}{ SUB - ST Being aggressive while driving } & Negative Ranks & $2^{(a)}$ & 7.00 & 14.00 \\
\hline & Positive Ranks & $39^{(b)}$ & 21.72 & 847.00 \\
\hline & Ties & $9^{(c)}$ & & \\
\hline & Total & 50 & & \\
\hline
\end{tabular}
(a) SUB $<$ ST
(b) SUB > ST
(c) $\mathrm{SUB}=\mathrm{ST}$ 
Table 5: Test Statistics ${ }^{(b)}$

\begin{tabular}{ccccc}
\hline & $\begin{array}{c}\text { SUB - ST Calling } \\
\text { without kit... }\end{array}$ & $\begin{array}{c}\text { SUB - ST Answering } \\
\text { without kit... }\end{array}$ & $\begin{array}{c}\text { SUB - ST Texting } \\
\text { while driving }\end{array}$ & $\begin{array}{c}\text { SUB - ST Being } \\
\text { aggressive while driving }\end{array}$ \\
\hline Z & $-5.205^{(a)}$ & $-4.267^{(a)}$ & $-3.502^{(a)}$ & $-5.640^{(a)}$ \\
$\begin{array}{c}\text { Asymp. Sig. }(2 \\
\text { tailed) }\end{array}$ & .000 & .000 & .000 & .000 \\
\hline
\end{tabular}

(a) Based on negative ranks.

(b) Wilcoxon Signed Ranks Test

\section{Discussion}

In Africa around 59000 people lost their lives in road accident in 1990. By 2020, there could be an increase in deaths of more than $140 \%$ (Kopits \& Cropper, 2005). Over the last three decades it can see that the number of road traffic injuries and deaths have been increasing (Adeloye et al., 2016). In Cameroon one of the most fatal sections concerns the triangle between Yaoundé-Douala, Douala-Bafoussam, Bafoussam-Yaoundé. Sobngwi-Tambekou et al. (2010) studied specifically what happened on the Yaoundé-Douala section by analysing police rapports made out in 2004 and 2007. They identified mechanical failures, hazardous overtaking and excessive speed as the main causes of fatal accidents. In their study the authors do not refer to the mobile phone which was however already considered to be one the main cause of road accidents in $2003^{1}$. Cameroon like other countries, has undergone a rapid evolution of the telephone and more particularly the mobile which has become considerably democratized, becoming a staple (Aker \& Mbiti, 2010).

The aim of this study carried out among drivers using the Yaoundé-Obala section was to investigate the relationship of Cameroon drivers with rules and to check the effectiveness of the substitution instructions to eliminate a possible social desirability or normative pressure in standard answers.

The assumption that there is a significant difference between standard and substitution conditions is partly verified. With a large effect size, the following conditions: respect of speed limits, concentration while driving, calling without kit or bluetooth and being aggressive while driving appear as the most normative. In case of respectul conditions, drivers attribute to themselves a more exemplary behavior. In case of transgression conditions, drivers attribute the offences to the others. Studies dating from around 30 years with French drivers showed that drivers had few scruples about reporting offences they committed (Moget-Monseur and Beicheler-Fretel, 1985). According to Beicheler-Fretel and Moget (1989) there exists a global structure of the driver's behavior which constitutes "an intermediary criterion of predictability of risk of offences and accidents" (our translation). However we believe that 30 years after, respecting rules of the Highway Code has become normative in the sense that different road safety policies that have been implemented in most countries have globally contributed to an awareness of road prohibitions. In this study, Cameroon drivers appear aware of the rules to be respected or of what is socially desirable even if in reality they do not respect them. Hence the hypothesis can be put forward that if drivers had been asked to reply in order to be well thought of, another substitution method approach (Flament, 1999), they would have given the same answers in the standard condition.

It is well-known that speeding constitutes one of the leading causes of accident on the road (Sobngwi-Tambekou et al., 2010; WHO, 2015). The differences between what motorists declare for themselves and for others testify to a real problem in the relation to speed. By studying the normative behaviour on the road, it has been shown that respect of the speed limit was the most conditional scenario, that is the least respected (Gaymard 2007, 2016; Gaymard et al., 2011). It is the same case for aggressiveness which is not characteristic of their driving but characterizes other motorists' driving. Aggressiveness on the roads is considered to be a major traffic safety problem in several countries (Chliaoutakis et al., 2002; Deffenbacher et al., 2003; Dula \& Geller, 2003; Sullman, 2015). Drivers know that it is better to be courteous than aggressive at the wheel but

\footnotetext{
${ }^{1}$ http://www.panapress.com/Cameroon-plans-for-road-safety--13-474307-18-lang1-index.html
} 
behind this problem there are individual or personality factors. Studies have thus shown that individuals who can not face stress, feel anger and aggressiveness more when driving (Hoggan \& Dollard, 2007). There exist many studies on this subject that are based on the frustrationaggression model (Berkowitz, 1978; Dollard, Doob, Miller, Mowrer \& Sears, 1939) or the transactional cognitive model (Lazarus \& Folkman, 1984). Aggressiveness contributes to road insecurity and Öz, Özkan and Lajunen (2010) have shown the link between aggressiveness and collisions. But this is a problem that actually concerns all road users since drivers are equally sensitive to lack of courtesy on the part of pedestrians and in situations of interaction, they only express positive feelings if pedestrians are courteous (Gaymard, 2012). On analysing our results it can be seen that there are two situations which are not statistically significant. These are the use of the mobile with a kit or bluetooth and the practice of turning off one's mobile when driving. For the first situation, in Cameroon law prohibits hand-held mobile phone use when driving (WHO, 2015). This may explain why there is no more discrepancy between the normal and substitution condition. The second one that presents no difference between the standard and substitution instructions indicates that it is not a pro-normative situation. Turning off one's mobile when driving is neither prescribed by the law nor practiced.

These results confirm the efficacy of the substitution instructions in identifying particularly normative situations that present substantial gaps between standard and substitution conditions (Gaymard, 2003). Finally in the field of non legitimate or inexcusable transgressions, and unlike the field of conditionality, the rule seems to be not to admit them for oneself but to attribute them to others. Fighting against road insecurity requires investment on the human, environmental and legislative (enforcement) level, which explains that $90 \%$ of death on the road happen in low or intermediate income countries (WHO, 2013). Cameroon has been ranked a poor, large debtor country (Amin \& Dubois, 2009). Already faced with the carnage of the roads linked to human behavior but also to the state of vehicles and infrastructure, Cameroon must now face the development of the use of the mobile at the wheel, which can only be banned in this environment (Cameroun Tribune, 2013).

\section{References}

Abric, J.-C. (1993). Central system, peripheral system: their functions and roles in the dynamic of social representations. Papers on Social Representations, 2, 75-78.

Adeloye, D., Thompson, J.Y., Akanbi, M.A., Azuh, D., Samuel, V., Omoregbe, N., \& Ayo, C.K. (2016). The burden of road traffic crashes, injuries and deaths in Africa: a systematic review and meta-analysis. Bulletin of the World Health Organization, 94, 510-521A. doi: http://dx.doi.org/10.2471/BLT.15.163121

Aker, J.C., \& Mbiti, I.M. (2010). Mobile phones and economic development in Africa. Journal of Economic Perspectives, 24(3), 207-232. doi : 10.2139/ssrn.1629321

Amin, A.A., \& Dubois, J.L. (Eds.). (2009). Croissance et développement au Cameroun: D'une croissance équilibrée à un développement équitable. Bamenda: Langaa RPCIG

Asch, S. E. (1951). Effects of group pressure on the modification and distortion of judgments. In H. Guetzkow (Ed.), Groups, leadership and men (pp. 177-190). Pittsburgh, PA: Carnegie Press

Bauer, M., \& Gaskell, G. (1999). Towards a paradigm for research on social representations. Journal for the Theory of Social Behaviour, 29(2), 163-186.

Berkowitz, L. (1978). Whatever Happened to the Frustration-Aggression Hypothesis? American Behavioral Scientist, 21, 691-707.

Biecheler-Fretel, M.B., \& Moget, M. (1989). Le comportement de base de l'automobiliste: un critère intermédiaire de prédictibilité du risque d'infraction et d'accident. Recherche Transports Sécurité, 24, 3544.

Bounoungou, A.P. (2015). Repenser la visite technique des véhicules au Cameroun. Retrieved from http://www.journalducameroun.com/article.php?aid=19351

Cameroun Tribune (2010). Le téléphone au Volant. Retrieved from https://www.cameroontribune.cm/index.php?option=com_content\&view=article\&id=61570:le-telephone-au-volant\&catid=20:editorial\&ltemid $=2$

Cameroun Tribune (2013). Cameroun: Téléphoner ou conduire, il faut choisir. Retrieved from

http://www.237online.com/article-54670-cameroun-telephoner-ou-conduire-il-faut-choisir--cameroon.html

Campbell, A., Muncer S., Guy A., \& Banim, M. (1996). Social representations of agression : crossing the sex barrier. European Journal of Social Psychology, 26, 135-147. 
Chliaoutakis, J.E, Demakakos, P., Tzamalouka, G., Bakou, V., Koumaki, M., \& Darviri, C. (2002). Aggressive behavior while driving of self-reported car crashes. Journal of safety Research, 33(4), 431-43.

Cohen, J. (1988). Statistical power analysis for the behavioral sciences (2nd ed.). Hillsdale, NJ: Lawrence Earlbaum Associates.

Deffenbacher, J.L., Lynch, R.S., Filetti, L.B., Dahlen, E.R., \& Oetting, E.R. (2003). Anger, aggression, risky behavior, and crashes-related outcomes in three groups of drivers. Behavioural Research and Therapy, 41(3), 333-349.

Dipita, T. (2012). Contrôle technique: Douala a mal à ses véhicules. Retrieved from http://www.journalducameroun.com/article.php?aid=11381

Dollard, J., Doob, L.W., Miller, N.P., Mowrer, O.H., \& Sears, R.R. (1939). Frustration and Aggression. New Haven, CT: Yale University Press.

Dula, C.S., \& Geller, E.S. (2003). Risky, Aggressive, or Emotional Driving: Addressing the Need for Consistent Communication in Research. Journal of Safety Research, 34(5), 559-566.

Farr, R. (1987). Social representations: A French tradition of research. Journal for the Theory of Social Behaviour, 17, 343-365. doi: 10.1111/j.1468-5914.1987.tb00103.x

Farr, R. (1993). The theory of social representations: Whence and Whither? Papers on Social Representations, 2(3), 131-138.

Faucheux, C. \& Moscovici, S. (1967). Le style de comportement d'une minorité et son influence sur les réponses d'une majorité. Bulletin du C.E.R.P., 16(4), 337-360

Flament, C. (1999). La représentation sociale comme système normatif. Psychologie et Société, 1, 29-53.

Flament, C., \& Rouquette, M.L. (2003). Anatomie des idées ordinaires. Comment étudier les représentations sociales. Paris: Armand Colin.

Gaymard, S. (2003). Représentation sociale et modèles normatifs dans un contexte biculturel. Les Cahiers Internationaux de Psychologie Sociale, 58, 50-58.

Gaymard, S. (2007). La représentation de la conduite chez de jeunes conducteurs. Une étude de la conditionnalité routière. Recherche Transports Sécurité, 97, 339-359. doi:10.3166/rts.97.339-359

Gaymard, S. (2009). Norms in social representations: two studies with French young drivers. The European Journal of Psychology Applied to Legal Context, 1(2), 165-181

Gaymard, S. (2012). Pedestrian representation through the analysis of little stories. Psychology of Language and Communication, 16(3), 185-200. doi: 10.2478/v10057-012-0013-9

Gaymard, S. (2014). The theory of conditionality: an illustration of the place of norms in the field of social thinking. Journal for the Theory of Social Behaviour, 44(2), 229-247. doi: 10.1111/jtsb.12039

Gaymard, S. (2016). Conditionality and normative models in the field of social thinking. In Kathryn J. Fitzgerald (Ed), Social Roles \& Social Norms (pp. 1-13). New York, NY: Nova Science Publishers.

Gaymard, S., Allain, P., Osiurak, F. \& Le Gall, D. (2011). The conditions of respect of rules in young and elderly drivers: An exploratory study. The European Journal of Psychology Applied to Legal Context, 3(1), 11-28

Gaymard, S., \& Bessin, M. (2017). La influencia de modelos normativos en la muestra social del ciclomotor entre los jóvenes adolescentes: un estudio piloto/The influence of normative models in the social representation of the moped among young teenage boys: A pilot study. Securitas Vialis, online first. https://doi.org/10.1007/s12615-016-9082-1

Gaymard, S., \& Maurin, M. (2017). Rank Ordering of Questionnaire Items Using Wilks' Statistics: An Example of Application to Three Populations. Cross-Cultural Communication, 13(1), 1-9. doi: 10.39689138

Gaymard, S., \& Tiplica, T. (2014). Conditional respect towards the pedestrian: Differences between men and women and risk modeling by the Bayesian approach. Quality \& Quantity, 48(1), 91-110. doi: 10.1007/s11135-012-9751-y

Gaymard, S., Tiplica, T., Koh, P.P. \& Wong, Y.D. (2015). The social representation of the pedestrian in French and Asian cultures. Journal of Safety Health and Environmental Research, 11(2), 261-273.

Hoggan, B.L, \& Dollard, M.F. (2007). Effort-reward imbalance at work and driving anger in an Australian community sample: is there a link between work stress and road rage? Accident Analysis and Prevention 39(6), 1286-1295. doi: 10.1016/j.aap.2007.03.014

Howarth, C. (2006). A social representation is not a quiet thing: Exploring the critical potential of social representations theory. British Journal of Social Psychology, 45, 65-86.

Kopits, E., \& Cropper, M. (2005). Traffic fatalities and economic growth. Accident Analysis and Prevention, 37(1), 169-178. doi: 10.1016/j.aap.2004.04.006

Lazarus, R.S., \& Folkman, S. (1984). Stress, Appraisal and Coping. Springer: New York.

Lokoua, B. (2012). Cameroun: Le téléphone X1+ est une révolution technologique. Retrieved from http://cameroun.smetoolkit.org/cameroun/fr/content/fr/53995/Cameroun-Le-t\%C3\%A9l\%C3\%A9phoneX1-est-une-r\%C3\%A9volution-technologique-

McGreevy, J., Stevens, K.A., Ekeke Monono, M., Etoundi Mballa, G.A., Kouo Ngamby, M., Hyder, A.A., \& Juillard, C. (2014). Road traffic injuries in Yaoundé, Cameroon: A hospital-based pilot surveillance study. Injury, 45, 1687-1692. doi: 10.1016/j.injury.2014.05.001 
Moget-Monseur, M., \& Beicheler-Fretel, M.B. (1985). Le comportement de base du conducteur . Un essai de conceptualisation du système de normes légales et sociales de l'usager de la route. Cahiers d'études ONSER, 64, Arcueil : ONSER.

Moscovici, S. (1961). La psychanalyse, son image et son public. Paris: Presses Universitaires de France.

Moscovici, S. (1976). Social influence and social change. London: Academic Press.

Moscovici, S. (1980). Toward a theory of conversion behavior. In L. Berkowitz (Ed.), Advances in experimental social psychology (Vol. 13), (pp. 209-239). New York: Academic Press.

Moscovici, S. (1984). Préface. In C.Herzlich (Ed.), Santé et Maladie. Analyse d'une représentation sociale. Paris : Mouton

Moscovici, S. (1998). The history and actuality of social representations. In U. Flick (Ed.), The psychology of the social (pp. 209-247). Cambridge: Cambridge University Press

Moscovici, S. (1991). Psychologie des minorités actives $\left(3^{\text {rd }}\right.$ ed.). Paris : PUF

Moscovici, S. (2001). Why a theory of social representations? In K. Deaux \& G. Philogène (Eds.), Representations of the social. Bridging theoretical traditions (pp. 8-35). Oxford: Blackwell.

Mugny, G., \& Carugati, F. (1989). Social representations of intelligence. Cambridge: Cambridge Univerity Press.

Ngapout. M.A.(2015). Faut-il se fier à la visite technique des véhicules? Retrieved from https://www.cameroon-tribune.cm/index.php?option=com_content\&view=article\&id=91676:controle-desvehicules-faut-il-se-fier-a-la-visite-technique- $\&$ catid=4:societe\&ltemid=3\#contenu

Öz, B., Özkan, T., \& Lajunen, T. (2010). Professional and non-professional drivers' stress reactions and risky driving. Transportation Research Part F, 13(1), 32-40. doi: 10.1016/j.trf.2009.10.001

Pallant, J. (2007). SPSS survival manual-A step by step guide to data analysis using SPSS for windows (3rd ed.). Maidenhead: Open University Press.

Sammut, G., \& Bauer, M.W. (2011). Social Influence: modes and modalities. In D.Hook, B. Franks, \& M. Bauer (Eds.), Social Psychology of communication (pp. 87-106). London: Palgrave.

Sobngwi-Tambekou, J., Bhatti, J., Kounga, G., Salmi, L.R., \& Lagarde, E. (2010). Road traffic crashes on the Yaoundé-Douala road section, Cameroon. Accident Analysis and Prevention, 42(2), 422-426. doi: 10.1016/j.aap.2009.09.003

Sullman, M.J.M. (2015). The expression of anger on the road. Safety Science, 72, $153-159$. https://doi.org/10.1016/j.ssci.2014.08.013

Tikouoka, J.R. (2001). Tableau de bord sur les accidents de circulation au Cameroun. Retrieved from http://www.icicemac.com/nouvelle/index.php3

Wagner, W. (1993). Can representations explain social behaviour ? A discussion of social representations as rational systems. Papers on Social Representations, 2(3), 236-249.

World Health Organization (WHO) (2013). Global status report on road safety 2013. http://www.who.int/violence_injury_prevention/road_safety_status/2013/en/

World Health Organization (WHO) (2015). Global status report on road safety 2015.

http://www.who.int/violence_injury_prevention/road_safety_status/2015/en/ 